九州大学学術情報リポジトリ

Kyushu University Institutional Repository

\title{
Evaluation of Long-Term Application of Organic Residues on Accumulation of Organic Matter and Improvement of Soil Chemical Properties in a Clay Terrace Soil of Bangladesh
}

Egashira, Kazuhiko

Laboratory of Soil Science, Division of Soil Science and Plant Production, Dpartment of Plant Resoruces, Faculty of Agriculture, Kyushu University

Han, Jing-Long

Laboratory of Soil Science, Division of Soil Science and Plant Production, Dpartment of Plant Resoruces, Faculty of Agriculture, Kyushu University

Karim, A. J.M. Sirajul

Department of Soil Science, Bangabandhu Sheikh Mujibur Rahman Agricultural University

Abu Zofar Md. Moslehuddin

Department of Soil Science, Bangabandhu Agricultural University

他

https://doi.org/10.5109/4546

出版情報: 九州大学大学院農学研究院紀要. 48 (1/2)，pp.227-236，2003-10-01. Faculty of Agriculture, Kyushu University

バージョン：

権利関係 : 


\title{
Evaluation of Long-Term Application of Organic Residues on Accumulation of Organic Matter and Improvement of Soil Chemical Properties in a Clay Terrace Soil of Bangladesh
}

\author{
Kazuhiko EGASHIRA ${ }^{\dagger}$, Jing-Long HAN, A. J. M. Sirajul KARIM*, \\ Abu Zofar Md. MOSLEHUDDIN** and Yoshio YAMADA***
}

\author{
Laboratory of Soil Science, Division of Soil Science and Plant Production, \\ Department of Plant Resources, Faculty of Agriculture, \\ Kyushu University, Fukuoka 812-8581, Japan \\ (Received June 18, 2003 and accepted July 15, 2003)
}

\begin{abstract}
The field experiment on the long-term application of organic residues was started in 1988 at the farm of Bangabandhu Sheikh Mujibur Rahamn Agricultural University (BSMRAU; named as Institute of Postgraduate Studies in Agriculture (IPSA) until 1998) and is continued until now. Five kinds of organic residues (no-application, rice straw, green manure, compost, and cowdung) were applied every June to cover soil surface uniformly as a thin layer and incorporated into soil to the depth of $10 \mathrm{~cm}$. Rice (July to October) and wheat (mid-November or December to March) have been cultivated in rotation under the combination of five organic-residue treatments and three levels of inorganic $\mathrm{N}$ fertilizer. Improvement of chemical and physical properties of soils during the first 5 years was summarized and already reported along with the yields of rice and wheat (Karim et al., 1995). Soil samples were taken in April 2003 and analyzed for total $\mathrm{C}$ and $\mathrm{N}$, and cation exchange capacity to evaluate the accumulation of organic matter and the improvement of soil chemical properties after 15 years since the start of the experiment.

The organic matter and total $\mathrm{N}$ contents ranged from 9.7 to $15.2 \mathrm{~g} \mathrm{~kg}^{-1}$ and from 0.57 to $0.93 \mathrm{~g} \mathrm{~kg}^{-1}$, respectively. Statistical analysis indicated that the organic matter and total $\mathrm{N}$ contents of the soils treated with compost (Cp) and cowdung (Cd) were significantly higher than those of the control (Mo: no application). The organic matter and total $\mathrm{N}$ contents increased between the first 5 years and the present, but the difference in the contents between the two terms was rather greater for the control than for the organic-residue treatments under the N0 treatment (no application of $\mathrm{N}$ fertilizer). This means that the effect of continuous application of organic residues on the accumulation of organic matter is not positively indicated. Therefore, it is reasonable to consider that the increased level of organic matter performed in the early stage of the experiment is maintained by application of organic residues after 15 years. The CEC ranged between 12.9 and $16.0 \mathrm{cmol}_{\mathrm{c}} \mathrm{kg}^{-1}$. It was significantly higher for the $\mathrm{Cp}$ and $\mathrm{Cd}$ treatments and reflected the accumulation of organic matter.
\end{abstract}

Key words: Bangladesh, field experiment, long-term application of organic residues, organic matter, total $\mathrm{N}$.

\footnotetext{
* Department of Soil Science, Bangabandhu Sheikh Mujibur Rahman Agricultural University, Salna, Gazipur-1703, Bangladesh

** Department of Soil Science, Bangladesh Agricultural University, Mymensingh-2202, Bangladesh

*** Emeritus Professor of Kyushu University; First Team Leader of IPSA Project, JICA

+ Corresponding author (E-mail: kegashi@agr.kyushu-u.ac.jp)
} 


\section{INTRODUCTION}

Bangladesh is an agro-based country in South Asia, situated in the northeastern part of the Indian subcontinent. The country has $147,000 \mathrm{~km}^{2}$ in total land area and belongs to the tropical to subtropical monsoon climate with mean annual rainfall of $2,200 \mathrm{~mm}$. The greater part of the country exists on the Ganges-Brahmaputra delta and an average height of the land is $9 \mathrm{~m}$ above mean sea level (MSL). In terms of physiography, Bangladesh is divided into three main units consisting of Holocene floodplains, Pleistocene terraces, and Tertiary hills, occupying 80,8 , and $12 \%$, respectively. Terraces are 5 to $25 \mathrm{~m}$ above MSL and are called the Madhupur and Barind Tracts, situated in the central and northwestern parts, respectively, of the country.

Unconsolidated Madhupur Clay underlies in the Madhupur and Barind Tracts (Saheed, 1984). The parent Madhupur Clay is probably a Mio-Pliocene marine coastal formation and fairly homogeneous vertically and throughout its lateral extent; the depth is about $8 \mathrm{~m}$ near Dhaka, the capital. The Madhupur Clay was block-uplifted above sea level probably before the late Pleistocene, more than 10,000 years ago. Since then it has been subjected to soil forming processes. Terrace soils are classified to six general soil types according to the Bangladesh soil classification system, depending on the weathering of parent material, topography and drainage (FAO-UNDP, 1988).

Agriculture is the mainstay of the economy of Bangladesh; it contributes to over $30 \%$ of the gross domestic product and provides employment for about $60 \%$ of the labor force. Nearly $60 \%$ of the national land is cultivated for different crops. Paddy rice is the main crop cultivated in all of the three crop-growing seasons (early kharif, late kharif and rabi), occupying about $80 \%$ of the total cropped land (Ashan and Karim, 1988). Increase in the intensification of cropping due to population pressure, however, has caused a gradual reduction of soil fertility. An FAO report (FAO-UNDP-UNEP, 1994) estimated 65\% of agricultural land in Bangladesh suffers from soil fertility decline. Moslehuddin et al. (1997) reviewed the fertility status of Bangladesh soils and concluded that the overall status was not satisfactory; they stressed the need for fertility conservation.

Organic matter status has a first priority in conservation of soil fertility in Bangladesh. Approximately $60 \%$ of the soils contain less than $2 \%$ organic matter, and N percentage is very low (Zaman, 1986). This is especially true for upland soils. Most soils in the highlands $\left(F_{0}\right.$ : flood depth is less than $\left.0.3 \mathrm{~m}\right)$ to medium highlands $\left(F_{1}\right.$ : flood depth is 0.3 to $0.9 \mathrm{~m}$ ) to which most of terrace soils belong are extremely low in organic matter contents (Ashan and Karim, 1988). The addition of organic materials to soil through farmyard manures, compost and organic residues has been reduced considerably, because a major portion of these organic residues is used as fuel by the rural population (Ashan and Karim, 1988).

The field test of the long-term application of organic residues was started in 1988 at the farm of IPSA (Institute of Postgraduate Studies in Agriculture; now named as Bangabandhu Sheikh Mujibur Rahman Agricultural University (BSMRAU)), Gazipur, Bangladesh, in order to examine the effect of continuous application of organic residues on the accumulation of organic matter in a clay terrace soil. Since then, different types of organic residues have been annually added to the soil, and the results of the test until 5 years from the start were summarized by Karim et al. (1995). In the present study, total 
carbon and nitrogen contents, and cation exchange capacity were analyzed for the soils collected from the experimental plots at the BSMRAU farm on the first week of April 2003, after 15 years since initiation of the experiment, to evaluate effects of long-term application of organic residues on the accumulation of organic matter and the improvement of chemical properties of a clay terrace soil of Bangladesh.

\section{FIELD EXPERIMENT}

Description under this section was quoted from Karim et al. (1995).

\section{Location and agricultural environment}

The field experiment on the long-term application of organic residues was initiated in March 1988. The site of the experiment is the BSMRAU farm, located in Salna, Gazipur district, $40 \mathrm{~km}$ north of Dhaka, and situated in the center of the Madhupur Tract $\left(24^{\circ} 05^{\prime}\right.$ $\mathrm{N}, 90^{\circ} 16^{\prime} \mathrm{E}$ ) at $8.4 \mathrm{~m}$ above MSL. The land naturally had undulated topography and was covered by sal forest. It was deforestated about 5 years before initiation of the experiment and then leveled to develop the experimental farm.

The soil of the BSMRAU farm belongs to the Salna series of Shallow Red-Brown Terrace Soil according to the Bangladesh soil classification system and is nearly equivalent to Ochrepts in Soil Taxonomy. In general, Shallow Red-Brown Terrace Soil is moderately well to imperfectly drained, pale olive-brown to reddish-brown soils overlying grey, little-altered, Madhupur Clay at less than $90 \mathrm{~cm}$. It is a poor soil, handicapped more or less severely by rapid run-off, erodibility, impeded internal drainage, droughtness and low fertility (FAO-UNDP, 1988). The soil of the BSMRAU farm is silty clay loam in texture at the surface layer and silty clay in the subsurface, and principal clay minerals are clay mica, kaolinite and several types of interstratified minerals (Egashira, 1988).

Climate in the Madhupur Tract is dominated by the subtropical monsoon with most rainfall during the months of the premonsoon (early kharif) and monsoon (late kharif) seasons (April through October) and scanty rainfall during the dry (rabi) season (November to March). The rainfall in the rabi season is uncertain and unevenly distributed (Egashira and Karim, 2001). Irrigation is inevitable to cropping in the rabi season.

\section{Experimental design and cropping schedule}

The experiment was laid out in $5 \times 3$ factorial design with four replications. Four replications were later reduced to two because of too much labor for the management. Five treatments of organic residues and three levels of nitrogen fertilizer were arranged randomly in each replication. The dimension of each plot was $12 \mathrm{~m} \times 7 \mathrm{~m}$ having a plot-to-plot distance of $1.5 \mathrm{~m}$.

Rice and wheat were cultivated in rotation as the kharif and rabi crops, respectively. A high-yielding variety of T. aman, 'BR 14', is used and transplanted within July every year and harvested in October. 'Akbar', a high-yielding variety of wheat, is sown between mid-November and December and harvested in March in each year.

\section{Application of organic residues}

Organic residues were applied to the soil once (June) in every year at 20-25 days 
before transplantation of rice. This timing was determined to ensure rapid decomposition of organic residues according to the recommendation of the scientist of Bangladesh Rice Research Institute. Five kinds of organic residues were applied as follows:

Mo: no application of organic residues;

Rs: air-dry rice straw at the rate of $2.0 \mathrm{Mg} \mathrm{ha}^{-1}$;

$\mathrm{Gm}$ : fresh ipilipil leaves as green manure at the rate of $7.5 \mathrm{Mg} \mathrm{ha}^{-1}$;

$\mathrm{Cp}$ : compost at the rate of $25 \mathrm{Mg} \mathrm{ha} \mathrm{g}^{-1}$, and compost was made of rice straw and cowdung that were kept in successive layers of $15 \mathrm{~cm}$ in a pit of $1.5 \mathrm{~m}$ deep and allowed to rotten for 100 to 120 days;

$\mathrm{Cd}$ : fresh cowdung at the rate of $25 \mathrm{Mg} \mathrm{ha}^{-1}$.

Rates of application of organic residues were determined to ensure their uniform distribution as a thin layer over the soil surface. Organic residues were then incorporated into soil by power tiller to the maximum depth of $10 \mathrm{~cm}$.

\section{Fertilizer application}

Three levels of nitrogen fertilizer were applied in the form of urea for both crops. For rice the rate of application was 0,75 , and $100 \mathrm{~kg} \mathrm{ha}^{-1}$ as $\mathrm{N}$, and for wheat it was 0,80 , and $120 \mathrm{~kg} \mathrm{ha}^{-1}$ as $\mathrm{N}$. The three levels of $\mathrm{N}$ were designated as N0, N1, and N2 treatments in the increasing rate of application for both rice and wheat. One-third of total $\mathrm{N}$ in rice and half of total $\mathrm{N}$ in wheat were applied at final land preparation as basal-dressing. The rest of $\mathrm{N}$ was top-dressed in two equal splits at 20 to 25 days and 50 to 55 days after transplanting of rice seedlings or sowing of wheat seeds.

Triple superphosphate (TSP) and muriate of potash (MP) were applied to each plot at final land preparation to supply $\mathrm{P}$ and $\mathrm{K}$, respectively. TSP was applied at the rate of $100 \mathrm{~kg} \mathrm{ha}^{-1}$ as $\mathrm{P}_{2} \mathrm{O}_{5}$ for both crops, and MP was applied at the rates of 80 and $60 \mathrm{~kg} \mathrm{ha}^{-1}$ as $\mathrm{K}_{2} \mathrm{O}$ for rice and wheat, respectively.

\section{Cultivation practice}

The land for rice cultivation was ploughed by power tiller after wetting the soil by water. Bullocks-drawn wooden plough and ladder were used for puddling and leveling the soil. Thirty-five- to 40-day-old seedlings were transplanted at the rate of 3 to 4 seedlings per hill keeping a row-to-row spacing of $25 \mathrm{~cm}$ and a hill-to-hill spacing of $20 \mathrm{~cm}$. Two times of weeding were required: one at 20 to 25 days and the other at 40 to 45 days after transplantation of seedlings. No irrigation was required, but whenever the rainy season ceased early in September one irrigation was required.

Land preparation for wheat cultivation was rather difficult and time-consuming. This was due to the high clay content of the BSMRAU farm soil which created difficulty in attaining the optimum soil moisture condition at land preparation. The soil was essential to attain the field capacity at the start of ploughing. The land was first opened by tractor-driven mould-board plough followed by harrowing. After final land preparation wheat seeds were sown in lines at the rate of $120 \mathrm{~kg} \mathrm{ha}^{-1}$ keeping a row-to-row distance of $20 \mathrm{~cm}$. Weeding, thinning of wheat seedlings, and loosening of soil were done only once at 20 to 25 days after sowing of seeds. Three to 4 times of irrigation were required every year to fulfill the water requirement of wheat. 


\section{MATERIALS AND METHODS}

\section{Collection of soil samples}

Soil samples analyzed in the present study were collected at the first week of April 2003 from the experimental farm of BSMRAU. Fifteen samples representing 15 treatments ( 5 organic-residues $\times 3 \mathrm{~N}$-fertilizers) were taken from each plot of two replications and were mixed to make composite samples. Soil samples were taken at the depth of 0 to $15 \mathrm{~cm}$, air-dried, gently ground, and finally passed through a 2-mm sieve.

\section{Methods of soil analysis}

Total $\mathrm{C}$ and $\mathrm{N}$ contents in soil were determined by a $\mathrm{N} \cdot \mathrm{C}$-Analyzer (Sumigraph NC-80 Auto, Sumitomo Chemical Ltd.) (Editorial Committee for Methods of Soil Environmental Analysis, 1997). The total C content was multiplied by a factor of 1.724 to convert it to the organic matter content, under assumption of no contamination of inorganic carbonates. In the determination of CEC (cation exchange capacity) (Muramoto et al., 1992), soil was saturated with $\mathrm{NH}_{4}$ by washing with $1 \mathrm{M} \mathrm{NH}_{4} \mathrm{CH}_{3} \mathrm{COO}(\mathrm{pH} 7.0) . \quad \mathrm{NH}_{4}$ was extracted by washing with $10 \% \mathrm{KCl}$ solution and determined colorimetrically by the indophenol blue method (Editorial Committee for Methods of Soil Environmental Analysis, 1997). The determination was made in duplicate to take average.

\section{Statistical analysis}

The Duncan's multiple range test was applied to the statistical analysis of the experimental results.

\section{RESULTS}

The organic matter and total $\mathrm{N}$ contents were assessed as an index of the accumulation of organic matter in soil. The results are shown in Table 1. The organic matter content ranged from $9.7 \mathrm{mg} \mathrm{kg}^{-1}$ in the N1Rs treatment to $15.2 \mathrm{~g} \mathrm{~kg}^{-1}$ in the N2Cd treatment, and the total $\mathrm{N}$ content was in a range between $0.57 \mathrm{mg} \mathrm{kg}^{-1}$ in the N0Rs treatment and $0.93 \mathrm{~g} \mathrm{~kg}^{-1}$ in the N2Cd treatment. The highest values were around 1.6 times of the lowest ones. Among the organic-residue treatments, the Rs (rice straw) treatment showed that the organic matter and total $\mathrm{N}$ contents were nearly equal to or lower than the contents of the Mo (no application) treatment, irrespective of the $\mathrm{N}$ levels. It indicates no effect of the Rs treatment in the present study on the accumulation of organic matter. In the other three treatments, the organic matter and total $\mathrm{N}$ contents were nearly equal to or higher than the contents of the Mo treatment. However, the organic matter content was still below the critical value of $20 \mathrm{~g} \mathrm{~kg}^{-1}$ (Zaman, 1986). Accumulation of organic matter was promoted by application of $\mathrm{N}$ fertilizer in the $\mathrm{Cp}$ (compost) and $\mathrm{Cd}$ (cowdung) treatments, whereas such effect was not noticed in the Gm (green manure) treatment.

The CEC was assessed as an index of the improvement of chemical properties of soil and is given in Table 1 . The CEC ranged between $12.9 \mathrm{cmol}_{c} \mathrm{~kg}^{-1}$ in the NOMo treatment and $16.0 \mathrm{cmol}_{\mathrm{c}} \mathrm{kg}^{-1}$ in the N2Cd treatment. The difference between them was 1.24 times. The CEC was somewhat higher for the $\mathrm{Cp}$ and Cd treatments than for the other three treatments in the respective $\mathrm{N}$ levels. It probably reflects the relatively high organic 
Table 1. Organic matter and total $\mathrm{N}$ contents and CEC of soils

\begin{tabular}{cccc}
\hline Treatment $^{\mathrm{a}}$ & $\begin{array}{c}\text { Organic } \\
\text { matter } \\
\left(\mathrm{g} \mathrm{kg}^{-1}\right)\end{array}$ & $\begin{array}{c}\text { Total N } \\
\left(\mathrm{g} \mathrm{kg}^{-1}\right)\end{array}$ & $\begin{array}{l}\text { CEC } \\
\left(\mathrm{cmol}_{\mathrm{c}} \mathrm{kg}^{-1}\right)\end{array}$ \\
\hline N0Mo & 11.4 & 0.68 & 12.9 \\
$\mathrm{Rs}$ & 9.8 & 0.57 & 14.1 \\
$\mathrm{Gm}$ & 12.4 & 0.75 & 14.1 \\
$\mathrm{Cp}$ & 12.6 & 0.78 & 15.2 \\
$\mathrm{Cd}$ & 11.2 & 0.65 & 14.9 \\
\hline N1Mo & 10.9 & 0.66 & 14.0 \\
Rs & 9.7 & 0.58 & 13.4 \\
$\mathrm{Gm}$ & 12.7 & 0.78 & 14.4 \\
$\mathrm{Cp}$ & 14.1 & 0.84 & 15.1 \\
$\mathrm{Cd}$ & 12.9 & 0.78 & 14.3 \\
\hline N2Mo & 11.8 & 0.70 & 14.2 \\
$\mathrm{Rs}$ & 12.1 & 0.71 & 14.2 \\
$\mathrm{Gm}$ & 11.5 & 0.67 & 14.7 \\
$\mathrm{Cp}$ & 14.2 & 0.85 & 15.7 \\
$\mathrm{Cd}$ & 15.2 & 0.93 & 16.0 \\
\hline
\end{tabular}

${ }^{\mathrm{a}}$ Refer to the text for abbreviations.

matter content in the former treatments.

\section{DISCUSSION}

\section{Accumulation of organic matter}

The organic matter contents of the respective organic-residue treatments calculated as the average of their N0, N1, and N2 treatments and statistical analysis by the Duncan's multiple range test are shown in Table 2 . The corresponding values and analysis to the total $\mathrm{N}$ content are given in Table 3. Both organic matter and total $\mathrm{N}$ contents were in the order of the $\mathrm{Cp}>\mathrm{Cd}>\mathrm{Gm}>\mathrm{Mo}>\mathrm{Rs}$ treatments. The organic matter and total $\mathrm{N}$ contents of the Rs treatment was not statistically different from those of the Mo treatment. This is partly due to the low application level $\left(2.0 \mathrm{Mg} \mathrm{ha}^{-1}\right)$ of rice straw in the Rs treatment of

Table 2. Statistical difference in the organic matter content between the treatments of different organic residues

\begin{tabular}{cccl}
\hline \multirow{2}{*}{ Treatment $^{\mathrm{a}}$} & $\begin{array}{l}\text { Average } \\
\left(\mathrm{g} \mathrm{kg}^{-1}\right)\end{array}$ & \multicolumn{2}{c}{ Significant level $^{\mathrm{b}}$} \\
\cline { 3 - 4 } & 11.4 & $\mathrm{~b} \%$ & $1 \%$ \\
\hline $\mathrm{Mo}$ & 10.5 & $\mathrm{c}$ & $\mathrm{AB}$ \\
$\mathrm{Rs}$ & 12.2 & $\mathrm{abc}$ & $\mathrm{AB}$ \\
$\mathrm{Gm}$ & 13.6 & $\mathrm{a}$ & $\mathrm{A}$ \\
$\mathrm{Cp}$ & 13.1 & $\mathrm{ab}$ & $\mathrm{AB}$ \\
$\mathrm{Cd}$ &
\end{tabular}

${ }^{\text {a }}$ Refer to the text for abbreviations.

' Different letters mean significant difference at $5 \%$ or $1 \%$ level. 
Table 3. Statistical difference in the total $N$ content between the treatments of different organic residues

\begin{tabular}{ccll}
\hline Treatment $^{\mathrm{a}}$ & $\begin{array}{l}\text { Average } \\
\left(\mathrm{g} \mathrm{kg}^{-1}\right)\end{array}$ & \multicolumn{2}{c}{ Significant level } \\
\cline { 2 - 4 } & 0.68 & $\mathrm{~b} \%$ & $1 \%$ \\
\hline Mo & 0.62 & $\mathrm{bc}$ & $\mathrm{A}$ \\
$\mathrm{Rs}$ & 0.73 & $\mathrm{c}$ & $\mathrm{A}$ \\
$\mathrm{Gm}$ & 0.82 & $\mathrm{a} c$ & $\mathrm{~A}$ \\
$\mathrm{Cp}$ & 0.79 & $\mathrm{ab}$ & $\mathrm{A}$ \\
$\mathrm{Cd}$ & &
\end{tabular}

a Refer to the text for abbreviations.

${ }^{b}$ Different letters mean significant difference at $5 \%$ or $1 \%$ level.

the present experiment. The organic matter and total $\mathrm{N}$ contents of the $\mathrm{Cp}$ and $\mathrm{Cd}$ treatments were not statistically different with each other but were significantly higher than those of the Mo treatment at the $5 \%$ level with the differences of $1.7-2.2 \mathrm{~g} \mathrm{~kg}^{-1}$ in organic matter and $0.11-0.14 \mathrm{~g} \mathrm{~kg}^{-1}$ in total $\mathrm{N}$. The organic matter and total $\mathrm{N}$ contents of the $\mathrm{Gm}$ treatment were not statistically different from those of the other three organic-residue treatments and the Mo treatment. Based on the above statement, the effectiveness of the application of organic residues to accumulate organic matter in the clay terrace soil of Bangladesh was evaluated, and application of compost was estimated to be most effective followed by cowdung.

The organic matter and total $\mathrm{N}$ contents of the respective $\mathrm{N}$ treatments were calculated as the average of their five organic-residue treatments. The average organic matter content was $11.5,12.1$, and $13.0 \mathrm{~g} \mathrm{~kg}^{-1}$ and the average total $\mathrm{N}$ content was $0.69,0.73$, and $0.77 \mathrm{~g} \mathrm{~kg}^{-1}$ for the N0, N1, and N2 treatments, respectively. The values increased with the increasing $\mathrm{N}$ application level, but statistical analysis by the Duncan's multiple range test indicated that there was no significant difference among the three $\mathrm{N}$ levels in both organic matter and total $\mathrm{N}$ contents.

In Table 4, the organic matter contents of the respective organic-residue treatments under the N0 level in the first 5 years $(1989 \sim 1993)$ and in the present (2003) are shown along with the initial values before experiment. The corresponding values for the total $\mathrm{N}$ content are given in Table 5. Soil was taken from the depth of 0 to $15 \mathrm{~cm}$ in the present study, and hence the values of the present study are comparable with the average of the values of $0-5$ and $10-15 \mathrm{~cm}$ depths in the previous report (Karim et al., 1995). The organic matter content of the soils treated with different organic residues was higher for the present than for the first 5 years, except for the Rs treatment, and the difference in the organic matter content between the two terms was $2.4,1.9$, and $1.6 \mathrm{~g} \mathrm{~kg}^{-1}$ for the $\mathrm{Gm}$, $\mathrm{Cp}$, and $\mathrm{Cd}$ treatments. The organic matter content of the Mo treatment also increased from the first 5 years to the present, and the difference of $3.3 \mathrm{~g} \mathrm{~kg}^{-1}$ in the Mo treatment was greater than the differences in all organic-residue treatments. Since no organic residue has been applied in the Mo treatment, the increase of the organic matter content in the Mo plot should be ascribed to the remaining or addition of crop residues like stems and roots. Therefore, the increase in the organic matter content observed in the organic-residue treatments between the first 5 years and the present cannot be always ascribed to the application of organic residues. Namely, the effect of continuous appli- 
Table 4. Comparison of the organic matter content under the N0 treatment between the previous and present studies

\begin{tabular}{|c|c|c|c|}
\hline \multirow{2}{*}{$\begin{array}{l}\text { Treatment } \\
\& \\
\text { depth }(\mathrm{cm})\end{array}$} & \multicolumn{3}{|c|}{ Organic matter content $\left(\mathrm{g} \mathrm{kg}^{-1}\right)$} \\
\hline & $\begin{array}{l}\text { Before } \\
\text { experiment }\end{array}$ & $\begin{array}{l}\text { Average of the first } 5 \\
\text { years }(1989 \sim 1993)\end{array}$ & $\begin{array}{l}\text { Present } \\
(2003)\end{array}$ \\
\hline Mo $0-5$ & 7.2 & 9.0 & \\
\hline $10-15$ & 6.6 & 7.1 & \\
\hline Average & 6.9 & 8.1 & 11.4 \\
\hline Rs $0-5$ & & 11.2 & \\
\hline $10-15$ & & 8.0 & \\
\hline Average & & 9.6 & 9.8 \\
\hline Gm $0-5$ & & 10.9 & \\
\hline $10-15$ & & 9.0 & \\
\hline Average & & 10.0 & 12.4 \\
\hline Cp $0-5$ & & 13.3 & \\
\hline $10-15$ & & 8.0 & \\
\hline Average & & 10.7 & 12.6 \\
\hline Cd $0-5$ & & 12.0 & \\
\hline $10-15$ & & 7.1 & \\
\hline Average & & 9.6 & 11.2 \\
\hline
\end{tabular}

${ }^{\mathrm{a}}$ Refer to the text for abbreviations.

Table 5. Comparison of the total $\mathrm{N}$ content under the N0 treatment between the previous and present studies

\begin{tabular}{lccc}
\hline Treatment & \multicolumn{3}{c}{ Total N content $\left(\mathrm{g} \mathrm{kg}^{-1}\right)$} \\
\cline { 2 - 4 } $\begin{array}{l}\mathrm{a} \\
\text { depth }(\mathrm{cm})\end{array}$ & $\begin{array}{l}\text { Before } \\
\text { experiment }\end{array}$ & $\begin{array}{l}\text { Average of the first } 5 \\
\text { years }(1989 \sim 1993)\end{array}$ & $\begin{array}{l}\text { Present } \\
(2003)\end{array}$ \\
\hline Mo $0-5$ & 0.30 & 0.48 & \\
$10-15$ & 0.25 & 0.27 & 0.68 \\
Average & 0.28 & 0.38 & \\
\hline Rs 0-5 & & 0.47 & \\
10-15 & & 0.28 & \\
Average & 0.38 & \\
\hline Gm 0-5 & & 0.56 & \\
10-15 & 0.36 & \\
Average & & 0.46 & 0.75 \\
\hline Cp 0-5 & & 0.59 & \\
10-15 & & 0.36 & \\
Average & & 0.48 & 0.65 \\
\hline Cd 0-5 & & 0.58 & \\
10-15 & & 0.38 & \\
Average & & 0.48 & \\
\hline
\end{tabular}

${ }^{\text {a }}$ Refer to the text for abbreviations.

cation of organic residues on the accumulation of organic matter in soil was not positively recognized in the present study.

As shown in Table 5, the total $\mathrm{N}$ content increased from the first 5 years to the present in all treatments. The increasing rate was greater for the total $\mathrm{N}$ content than for the 
organic matter content, but the same thing as the organic matter content was observed for the total $\mathrm{N}$ content. Namely, the difference in the total $\mathrm{N}$ content of the organic-residue treatments between the two terms did not exceed that of the Mo treatment.

As shown in Tables 4 and 5, the organic matter and total $\mathrm{N}$ contents quickly increased in the first 5 years of the experiment by application of organic residues and even in the Mo plot. The organic matter content varied with kinds or types of organic residues, and the order of organic residues in its content in soil was similar with one another between the first 5 years and the present. Therefore, it is reasonable to consider that application of organic residues on the accumulation of organic matter in the clay terrace soil of Bangladesh is most effective in the early stage of application and that this effect is maintained by continuous application of them.

The difference in the organic matter and total $\mathrm{N}$ contents observed between the first 5 years and the present might come from the difference in the determination methods in the previous and present studies (the wet combustion method for organic $\mathrm{C}$ and the Kjeldahl method for total $\mathrm{N}$ in the previous study (Karim et al., 1995)) or the assumption made for comparison of both data. Even if it is true, the statement described in the above can drawn.

\section{Improvement of soil chemical properties}

Table 6 shows the CEC of the respective organic-residue treatments calculated as the average of their N0, N1, and N2 treatments and statistical analysis by the Duncan's multiple range test. The CEC was in the order of the $\mathrm{Cp}>\mathrm{Cd}>\mathrm{Gm}>\mathrm{Rs}>$ Mo treatments and this order was the same as that of the organic matter content among the organic-residue treatments (Table 2). The CEC of the $\mathrm{Cp}$ and Cd treatments was significantly higher than that of the Mo treatment. The higher CEC of those treatments reflect their higher organic matter content, suggesting the improvement of soil chemical properties.

Table 6. Statistical difference in CEC between the treatments of different organic residues

\begin{tabular}{ccll}
\hline \multirow{2}{*}{ Treatment $^{\mathrm{a}}$} & $\begin{array}{l}\text { Average } \\
\left(\mathrm{cmol}_{\mathrm{c}} \mathrm{kg}^{-1}\right)\end{array}$ & \multicolumn{2}{c}{ Significant level } \\
\cline { 2 - 4 } & 13.7 & $\mathrm{c} \%$ & $\mathrm{c}$ \\
\hline Mo & 13.9 & $\mathrm{c}$ & $\mathrm{BC}$ \\
$\mathrm{Rs}$ & 14.4 & $\mathrm{bc}$ & $\mathrm{ABC}$ \\
$\mathrm{Gm}$ & 15.3 & $\mathrm{a}$ & $\mathrm{A}$ \\
$\mathrm{Cp}$ & 15.0 & $\mathrm{ab}$ & $\mathrm{AB}$ \\
$\mathrm{Cd}$ & & &
\end{tabular}

Refer to the text for abbreviations.

' Different letters mean significant difference at $5 \%$ or $1 \%$ level.

\section{CONCLUSIONS}

Application of compost and cowdung at the level of $25 \mathrm{Mg} \mathrm{ha}^{-1}$ once a year contributed to the accumulation of organic matter in a clay terrace soil of Bangladesh. However, the accumulation level of organic matter is still low after 15 years, and growth 
and yield of crops should be supported by application of chemical fertilizers.

\section{REFERENCES}

Ashan, E and Z. Karim 1988 Soil fertility and management research on upland soils in Bangladesh. In "Proceedings of the International Conference on the Management and Fertilization of Upland Soils in the Tropics and Subtropics", Nanjin, China, pp. 247-251

Editorial Committee for Methods of Soil Environmental Analysis 1997 Methods of Soil Environmental Analysis. Hakuyusha, Tokyo (in Japanese)

Egashira, K. 1988 Occurrence of interstratified minerals in Terrace Soils of Bangladesh. Bull. Inst. Trop., Agric. Kyushu Univ., 11: 23-43

Egashira, K. and A. J. M. S. Karim 2001 Recent rainfall conditions in Madhupur Tract of Bangladesh. $J$. Fac. Agric., Kyushu Univ., 46: 69-74

FAO-UNDP 1988 Land Resources Appraisal of Bangladesh for Agricultural Development, Report No. 2, Agroecological Regions of Bangladesh, BGD/81/035. Technical Report No. 2, FAO, Rome (Italy)

FAO-UNDP-UNEP 1994 Land Degradation in South Asia: Its Severity, Causes and Effects upon the People. World Soil Resources Reports 78, FAO, Rome (Italy)

Karim, A. J. M. S., K. Egashira, Y. Yamada, J. Haider and K. Nahar 1995 Long-term application of organic residues to improve soil properties and to increase crop yield in terrace soil of Bangladesh. J. Fac. Agric., Kyushu Univ., 39: 149-165

Moslehuddin A. Z. M., S. Laizoo and K. Egashira 1997 Fertility status of Bangladesh soils-A review-. J. Fac. Agric., Kyushu Univ., 41: 257-267

Muramoto, J., I. Goto and M. Ninaki 1992 Rapid analysis of exchangeable cations and cation exchange capacity (CEC) of soils by a shaking extraction method. Jpn. J. Soil Sci. Plant Nutr., 63: 210-215 (in Japanese with English abstract)

Saheed, S. M. 1984 Soils of Bangladesh. In "Proceedings of the International Symposium on Soil Test Crop Response Studies", Bangladesh Agricultural Research Council and Soil Science Society of Bangladesh, Dhaka, pp. 107-129

Zaman, S. M. H. $\quad 1986$ Current Status and Prospects for Rainfed Foodgrain Production in Bangladesh. Bangladesh Rice Research Institute, Gazipur (Bangladesh) 